\title{
Sistem Informasi Pusat Data Dampak Kebakaran Hutan dan Lahan Berbasis Mobile Web di Provinsi Riau
}

\author{
Aidil Fitriansyah1, ${ }^{*}$, Alfirman² \\ 1,2 Sistem Informasi FMIPA Universitas Riau \\ (coresponding author) Aidil.fitriansyah@lecturer.unri.ac.id*
}

\begin{abstract}
Land and forest fires in Indonesia has been a problem that continues from year to year. While the information anywhere region or pin-point the fire became the most important hurdle to get the position or location of the fire area. as long as this information is granted only in terms of the quantity and location of land and forest fires. While information about the victim impact from forest fires and land not owned. In this research, using a Location based services (LBS) to indicate the position where the only occurrence of forest fire by sending the position coordinates. So also the victims as victims affected by ISPA, Died and displaced reportedly accompanied by coordinate neighborhoods' victims and the number of victims. The positions are then displayed shipped in a separate system in the form of Geographic Information System (GIS). In this report the system can display the position of the affected region and complete with the number of victims. Reporting data can be in the form of short Message System (SMS) and mobile web.
\end{abstract}

Keyword- Land and forest fires,Location based system (LBS), Geographic Information System (GIS), , Short Message System (SMS), web mobile

\begin{abstract}
Intisari-Kebakaran hutan dan lahan di Indonesia telah menjadi permasalahan yang terus berlanjut dari tahun ke tahun. Sedangkan Informasi mengenai dimana saja wilayah atau titik posisi kebakaran menjadi rintangan paling utama untuk mendapatkan posisi atau letak daerah yang terbakar. selama ini informasi yang diberikan hanya dalam bentuk jumlah dan lokasi terjadinya kebakaran hutan dan lahan. Sementara informasi mengenai korban dampak dari kebakaran hutan dan lahan tidak dimiliki. Pada penelitian ini, menggunakan sistemLocation based services (LBS) untuk menandakan posisi dimana saja terjadinya kebakaran hutan dan lahan dengan cara mengirimkan posisi koordinat. Begitu juga mengenai korban seperti korban terkena infeksi saluran pernafasan (ISPA), Meninggal dan mengungsi dilaporkan dengan disertai koordinat wilayah yang terdapat korban dan jumlah korban. Posisi-posisi yang dikirimkan tersebut kemudian di tampilkan di dalam sebuah sistem tersendiri dalam bentuk Geographic Information System (GIS). Pada sistem laporan ini dapat di tampilkan posisi wilayah yang terkena dampak dan lengkap dengan jumlah korban. Sementara pelaporan data bisa dalam bentuk short Message System (SMS), dan mobile web.
\end{abstract}

Kata Kunci- Kebakaran Hutan dan Lahan,Location Based System (LBS), Geografic Information System (GIS), short Message System (SMS), web mobile.

\section{PENDAHULUAN}

Pemerintah Indonesia dalam hal menghadapi bencana kebakaran lahan dan hutan selama ini mengalami permasalahan yang cukup berat. Karena akibat dari kebakaran tersebut tidak hanya permasalahan bagaimana memadamkan kebakaran tersebut tetapi akibat dari kebakaran tersebut juga menyebabkan beberapa permasalahan lainnya misalnya apabila kebakaran tersebut sampai kepemukiman masyarakat akan menyebabkan masyarakat meninggalkan tempat tinggalnya atau mengungsi. Akibat dari kebakaran yang mencakup area yang luas menimbulkan asap yang sangat kuat sehinggal mencemari udara dan menyebabkan sesak nafas.

Selama ini pemerintah melalui badan nasional penanggulangan bencana (BNPB) hanya terfokus pada data jumlah titik api dan penanganannya tetapi tidak memiliki berapa jumlah korban akibat dari bencana kebakaran lahan dan hutan. Ini dapat lihat dari situs BNPB yang tidak memiliki data korban dari bencana kebakaran hutan dan lahan. Pengalaman dari beberapa tahun kejadian dari kebakaran hutan dan lahan yang melanda Indonesia tidak pernah ada suatu situs atau badan yang memberikan perkembangan mengenai jumlah data korban akibat dari bencana kebakaran hutan dan lahan. Data tersebut bermanfaat terutama jika ingin menyalurkan bantuan ke daerah-daerah mana saja yang terdapat korban. Data korban akibat dari bencana kebakaran hutan dan lahan dapat berupa data korban yang mengungsi, data korban yang menderita infeksi saluran pernafasan (ISPA) dan data korban meninggal dunia. 
Pada penelitian ini akan dirancang sebuah sistem informasi berbasis GIS yang mampu menyediakan data-data lokasi titik kebakaran hutan dan lahan juga menyedikan data lokasi-lokasi yang terdapat korban bencana yang di sebabkan kebakaran hutan dan lahan. Penelitian ini diimplementasi dalam sebuah sistem informasi berbasis mobile web dan short mesage service (SMS). Pada sistem ini untuk mendapatkan suatu lokasi dengan mengetahui posisi global positioning system (GPS) menggunakan metode Location bases services (LBS). Data dikirm melalu antar muka berbasis mobile web atau dapat juga menggunakan SMS. Pada pelaksanaan pembuatan sistem informasi dilakukan menggunakan metode Waterfall. Karena perlunya proses yang terurut dalam pembuatan sistem ini maka digunakanlah metode Waterfall meliputi tahap, yaitu: Analisis, Desain, Coding, Pengujian, dan Pemeliharaan.

\section{TINJAUAN PUSTAKA}

Sistem Informasi adalah suatu sistem di dalam suatu organisasi yang mempertemukan kebutuhan pengolahan transaksi harian yang mendukung fungsi operasi organisasi yang bersifat manajerial dengan kegiatan starategi dari suatu organisasi untuk dapat menyediakan kepada pihak luar tertentu dengan laporan laporan yang diperlukan [1]

Location Based Services (LBS) adalah layanan informasi yang dapat diakses melalui mobile device dengan menggunakan mobile network, yang dilengkapi kemampuan untuk memanfaatkan lokasi dari mobile device tersebut. Oleh karena itu pengguna memberitahukan penyedia layanan untuk mendapatkan informasi yang dibutuhkan dengan referensi posisi pengguna. LBS digambarkan sebagai suatu layanan yang berada pada pertemuan teknologi yaitu: GIS, Internet Service, dan mobile Devices [2].

Penelitan terdahulu yang relevan mengunakan posisi GPS. Penelitian tersebutyaitu membuat suatu sistem untuk merekam posisi GPS dari suatu lokasi yang dilengkapi dengan gambar lokasi. Penelitian ini hanya merekamkan dan dapat juga membaca kembali data yang rekamkan. Untuk mendapatkan posisi GPS dilakukan dengan cara manual kemudian di inputkan ke sistem melalui sebuah aplikasi yang di jalankan pada perangkat Mobile. Pada penelitian tersebut juga hanya mengolah data perekaman suatu lokasi. Untuk mendapatkan posisi GPS juga didapatkan secara manual [3][4].

Penelitian lain juga melakukan perekaman terhadap suatu posisi. Hanya saja untuk mendapatkan koordinat GPS dapat dilakukan secara otomatis oleh aplikasi. Data koordinat hanya dibaca saja oleh aplikasi tetapi tidak dikirimkan ke server untuk disimpan ke database [5]. Penelitian yang akan dilakukan menggunakan LBS untuk memberikan lokasi informasi posisi korban dan titik api. Data bencana yang dilaporkankan ke server adalah jenis korban dan lokasi korban yang dilengkapi dengan koordinat posisi. Data tersebut dikirim menggunakan Short Message Service (SMS) mengikuti format tertentu. Data dalam bentuk SMS tersebut diolah secara otomatis dan selanjutnya akan ditampilkan dalam bentuk sistem informasi berbasis Web GIS secara online sehingga semua orang dapat mengakses informasi tersebut dengan memerlukan waktu tunda yang sedikit. Sistem ini juga menggunakan mobile web untuk menjalankan aplikasi, yaitu menjalankan aplikasi pada web browsing yang terdapat pada perangkat smartphone.

\section{METODE PENELITIAN}

\section{A. Desain Metode Pembuatan}

Mengenai metode yang digunakan dalam pelaksanaan penelitian ini yaitu menggunakan metode waterfall, dimana untuk pembuatan sebuah sistem tahapan-tahapan yang paling mudah dan terstruktur adalah menggunakan metode waterfall karena tahapan metode pembuatan sistem ini harus terlebih dahulu selesai antara satu tahap dengan tahap yang lainnya [6]. hasil akhir dari sistem ini adalah berupa sistem informasi data center korban dampak kebakaran hutan dan lahan. Berikut adalah tahapan-tahapan pembuatan yang dilakukan:

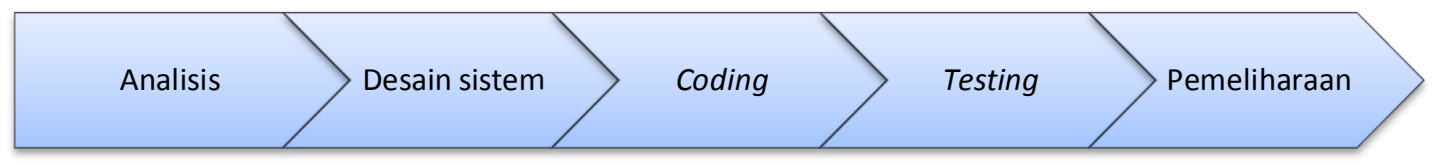

Gambar 1 Kerangka Pembangunan Sistem [6]

Metode waterfall yang terdiri dari lima tahapan yaitu analisa kebutuhan, desain sistem, penulisan kode program, testing dan pemeliharaan.

B. Metode Pengumpulan Data

Teknik pengambilan data yang digunakan dalam pengumpulan data pada penelitian ini sebagai berikut: 
1) Studi Pustaka

Studi pustaka merupakan salah satu teknik pengumpulan data berupa teori-teori yang berhubungan dengan permasalahan pada penyelesaian penelitian.

2) Studi Lapangan

Studi lapangan dilakukan oleh penulis dengan tujuan untuk mengetahui secara langsung bagaimana permasalahan yang peneliti angkat untuk dijadikan sebagai topik penelitian.

3) Wawancara

Dalam teknik wawancara, peneliti melakukan wawancara kepada warga, petugas di kelurahan dan petugas penanggulangan kebakaran hutan dan lahan dengan tujuan untuk mengetahui secara pasti bagaimana permasalahan yang ada dalam pelaporan korban dan titik api yang disebabkan kebakaran hutan dan lahan. Serta rumah sakit-rumah sakit yang biasanya menangani korban dampak kebakaran hutan dan Iahan.

\section{Alat dan Bahan}

Dalam mengerjakan penelitian ini, mulai dari mendesain sampai tahapan pemograman, menggunakan perlengkapan komputer. Adapun peralatan-peralatan yang dibutuhkan adalah sebagai berikut:

1) Perangkat Keras

Perangkat Keras (Hardware) yang digunakan adalah:

a. Perangkat laptop dengan spesifikasi Processor intel (R) Core (TM) i3-2310M CPU @ 210 GHz (4CPUs), Harddisk 500GB, RAM 4 GB.

b. SmartPhone Android support GPS.

2) Perangkat lunak atau Software yang terdiri dari:

a. App Inventor (version v2.3), digunakan sebagai media pembuatan aplikasi.

b. Java Development Kit (JDK), agar komputer dapat membaca bahasa pemrograman Java.

c. Google App Engine, digunakan untuk membuka App Inventor pada browser.

d. Mozilla firefox, digunakan sebagai media aplikasi App Inventor secara online maupun offline.

e. Microsoft Office Visio 2007, digunakan untuk perancangan sistem dan atau diagram aplikasi.

f. Photoshop CS5, digunakan untuk pembuatan tampilan user interface dan atau editing atribut foto.

g. Star UML, digunakan untuk pembuatan perancanan sistem dan diagram aplikasi.

h. Hosting dan Domain.

i. Notepad++ untuk penulisan program.

\section{HASIL DAN PEMBAHASAN}

Sebelum melakukan pembuatan sistem perlu adanya analisa pada sistem yang ada atau yang sedang berjalan pada sistem informasi korban dampak kebakaran hutan dan lahan. Hal ini dimaksud agar memudahkan peneliti dalam pembuatan sistem sehingga apa yang di inginkan berjalan sesuai dengan apa yang diharapkan.

\section{A. Analisa Sistem yang sedang berjalan}

Sistem informasi korban dampak kebakaran hutan dan lahan dalam penyimpanan data dilakukan masih menggunakan sistem manual saat sekarang ini yaitu dengan mencatat data korban pada buku besar dan belum memiliki database dan aplikasi khusus dalam penyimpanan berkas pengarsipan sekarang ini.

\section{B. Perancangan Sistem Informasi}

Pada tahap ini adalah melakukan perancangan program dimana nantinya akan menentukan hasil akhir dari aplikasi yang telah dibuat, yaitu meliputi perancangan sistem, user interface, dan activity yang akan dijalankan oleh user. Pada perancangan sistem informasi yaitu melakukan perencanaan mengenai sistem aktivitas yang ada pada sistem informasi dan akan dibuat menggunakan metode UML (Unified Modelling language) [6]. UML adalah bahasa standar yang digunakan untuk menjelaskan dan menvisualisasikan artifak dari prosesanalisis dan desain berorientasi objek. UML memungkinan developer melakukan pemodelan secara visual, yaitu penekanan pada penggambaran.

Pemodelan visual membantu untuk menangkap struktur dan perilaku dari objek, mempermudah penggambaran interaksi antara elemen dalam sistem, dan mempertahankan konsistensi antara desain dan implementasi dalam pemrograman. Berikut adalah gambaran perancangan sistem informasi data center korban dambak kebakaran hutan dan lahandi Provinsi Riau dengan metode UML.

Diagram ini menjelaskan keterkaitan aksi-aksi yang dilakukan oleh masing-masing aktor yang terlibat dalam sistem informasi data center korban dambak kebakaran hutan dan lahan di Provinsi Riau. 


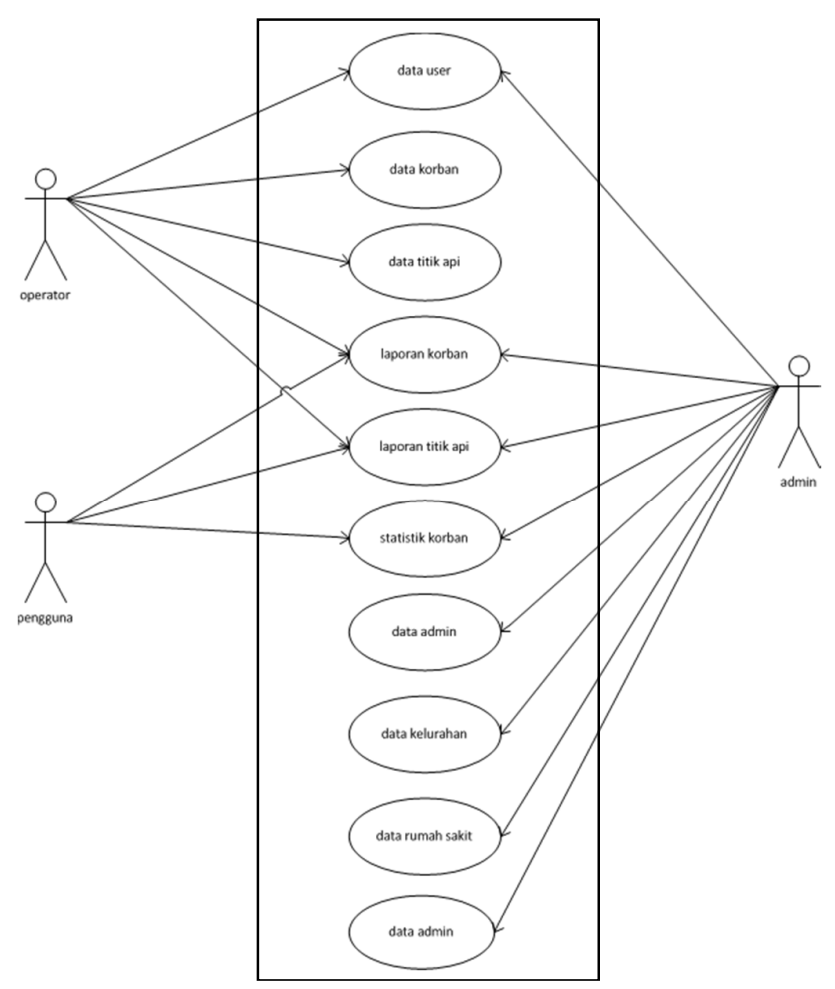

Gambar 2 Usecase Diagram sistem informasi dat sistem informasi data center korban dambak kebakaran hutan dan lahan di Provinsi Riau.

Usecase diagram sistem informasi dat sistem informasi data center korban dambak kebakaran hutan dan lahan di Provinsi Riau pada gambar 2, memperlihatkan hal-hal apa saja yang dilakukan oleh setiap aktor yang terlibat dalam sistem data center. Aktor yang terlibat dalam sistem informasi dat sistem informasi data center korban dambak kebakaran hutan dan lahan di Provinsi Riau adalah:

1) Petugas operator yang menjalankan sistem pelaporan baik yang menggunakan SMS, sistem web Mobile dan sistem desktop.

2) Admin sistem informasi dat sistem informasi data center korban dambak kebakaran hutan dan lahan di Provinsi Riau.

3) Pengguna yaitu yang dapat melihat data-data informasi yang dihasilkan.

Masing-masing aktor tersebut memiliki peran masing-masing.

Petugas operator dapat melakukan hal-hal berikut, yaitu:

1) Login ke dalam sistem user untuk memberikan laporan titik api dan korban.

2) Mengupdate data keadaan terbaru.

3) Melihat laporan korban dan titik api.

Admin dapat melakukan hal-hal berikut, yaitu:

1) Login ke dalam sistem admin untuk mengupdate data operator, data admin.

2) Mengupdate data keadaan terbaru.

3) Melihat laporan korban dan titik api.

Pengguna dapat melakukan hal-hal berikut, yaitu:

1) Melihat laporan korban dan titik api.

2) Melihat didaerah mana saja terdapat titik api dan korban

1) Model Arsitektur Sistem

Pada gambar 3 berikut ini menunjukan Model Arsitektur sistem informasi data dampak kebakaran hutan dan lahan secara keseluruhan. 


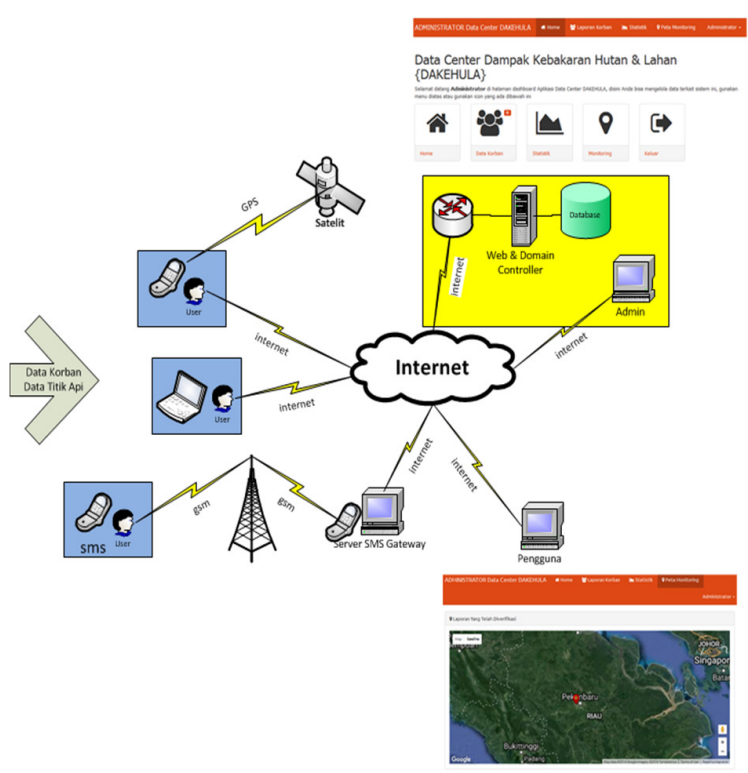

Gambar 3 Model Arsitektur Sistem Informasi Data Center Korban Dampak Kebakaran Hutan dan Lahan

Sistem ini dapat memberikan input menggunakan SMS. Input data SMS dilakukan untuk menjangkau daerah yang tidak memiliki koneksi jaringan internet. Data SMS dikirim operator ke SMS gateway server untuk diteruskan secara otomatis ke server data center. Data yang dikirim oleh operator ke server adalah data korban-korban dari dampak kebakaran hutan dan lahan serta data posisi kebakaran hutan dan lahan hasil laporan pandangan mata. Jika wilayah yang memiliki koneksi internet operator dapat mengirimkan data menggunakan aplikasi pelaporan berbasis web mobile dan berbasis desktop. Aplikasi pelaporan berbasis web mobile dapat mengenali LBS secara otomatis sehingga data yang dikirim memiliki koordinat wilayah yang terkena dampak kebakaran hutan dan lahan. Semua data yang di inputkan oleh operator dengan tiga cara tersebut akan menuju satu basis data yang berada di server. Data berupa lokasi titik api kebakaran hutan dan lahan serta data mengenai jumlah yang terkena dampak kebakaran hutan.

Sistem informasi pada sisi administrator dapat melakukan beberapa hal yaitu menambahkan data operator baik itu operator yang mneggunakan SMS dan operator yang menggunakan web mobile dan alikasi desktop. Pada data operator yang menggunakan SMS disertai data koordinat LBS wilayahnya.

Sistem informasi pada sisi administrator juga dapat mengolah data koordinat wilayah yang terkena dampak kebakan hutan dan lahan.

2) Model Proses

Rancangan model yang dibuat merupakan diagram alir dari system yang dibangun secara keseluruhan. Untuk lebih jelasnya dapat dilihat pada gambar 4.



Gambar 4 Diagram konteks 


\section{Pengujian Program}

Pengujian aplikasi dilakukan untuk mengetahui kesalahan-kesalahan yang ada dan untuk memastikan kebenaran dalam penulisan kode yang terdapat di dalam system yang dbuat. Untuk pengujian sistem yang digunakan yaitu metode blackbox testing. Seperti pada table 1 :

Tabel 1 HASIL PENGUJIAN PROGAM MENGGUNAKAN BLACKBOX TEST

\begin{tabular}{|c|c|c|c|c|}
\hline No & Skenario & Test Case & Harapan & Hasil \\
\hline 1 & Berhasil melakukan login & $\begin{array}{l}\text { Username: user, } \\
\text { password: user }\end{array}$ & Berhasil masuk ke sistem & Valid \\
\hline 2 & Mengisi login dengan user yang salah & Username:, password: & Username atau, password anda salah & Valid \\
\hline 3 & Berhasil menambahkan data operator & $\begin{array}{l}\text { Mengisi semua record } \\
\text { data operator. }\end{array}$ & & Valid \\
\hline 4 & Berhasil Menginputkan data korban & $\begin{array}{l}\text { Tambah, update, melihat } \\
\text { data korban }\end{array}$ & $\begin{array}{l}\text { Data korban yang ditambahkan dapat } \\
\text { dilihat, ditambah, di update }\end{array}$ & Valid \\
\hline 5 & Berhasil mengirim data dengan SMS & $\begin{array}{l}\text { Mengirim SMS sesuai } \\
\text { format }\end{array}$ & $\begin{array}{l}\text { Data yang di kirim berhasil masuk kedalam } \\
\text { data center }\end{array}$ & Valid \\
\hline 6 & $\begin{array}{l}\text { Tidak mengisi data SMS sesuai dengan } \\
\text { format }\end{array}$ & $\begin{array}{l}\text { Mengisi SMS tidak sesuai } \\
\text { format }\end{array}$ & $\begin{array}{l}\text { Data yang di kirim tidak berhasil masuk } \\
\text { kedalam data center }\end{array}$ & Valid \\
\hline 7 & Berhasil mengirim data titik api & $\begin{array}{l}\text { Menambahkan lokasi titik } \\
\text { api baru }\end{array}$ & $\begin{array}{l}\text { Data statistik dan laporan titik api } \\
\text { ditambahkan, dan di update. }\end{array}$ & Valid \\
\hline 8 & Berhasil melihat lokasi titik api & $\begin{array}{l}\text { Memilih laporan lokasi titik } \\
\text { api }\end{array}$ & $\begin{array}{l}\text { Menampilkan titik api yang ada pada peta } \\
\text { digital }\end{array}$ & Valid \\
\hline 9 & $\begin{array}{l}\text { Berhasil melihat rekap korban } \\
\text { keseluruhan }\end{array}$ & Memilih laporan korban & $\begin{array}{l}\text { Menampilkan data rekap keseluruhan } \\
\text { korban }\end{array}$ & Valid \\
\hline 10 & $\begin{array}{l}\text { Berhasil melihat rekap korban per } \\
\text { kategori }\end{array}$ & $\begin{array}{l}\text { Memilik filter laporan } \\
\text { berdasarkan jenis korban }\end{array}$ & Menampilkan laporan berdasarkan pilihan & Valid \\
\hline 11 & Berhasil melihat statistik korban & Memilih menu statistik & Menampilkan laporan statistik & Valid \\
\hline 12 & Berhasil melihat statistik titik api & Memilih menu statistik & Menampilkan laporan statistik & Valid \\
\hline
\end{tabular}

\section{Implementasi Sistem}

Tahapan implementasi merupakan tahapan setelah dilakukan tahapan rancangan, coding dan pengujian. Aplikasi sistem informasi data center dampak kebakaran hutan dan lahan merupakan aplikasi berbasis web baik pada sisi admin, pengguna dan operator. Hanya pada bagian operator pada daerah yang tidak terjangkau dengan koneksi internet yang menggunakan sistem SMS Gateway. Untuk mengakses sistem terlebih dahulu harus login. Pada gambar $5 \mathrm{~b}$ berikut ini adalah tampilan login dari aplikasi.



Gambar 5a Tampilan Awal Sistem 




Gambar 5b Form Login Ke Sistem

Untuk pelaporan titik api dan korban ke server dapat dilakukan dengan dua cara yaitu pertama dengan menggunakan SMS gateway (gambar 6a) digunakan pada wilayah yang tidak terdapat koneksi internet. Cara kedua yaitu menggunakan aplikasi pelaporan yang berbasis web mobile (gambar $6 \mathrm{~b}$ ) untuk wilayah yang memiliki koneksi internet. Kelebihan pada cara kedua yaitu data yang dilaporkan memiliki posisi atau koordinat wilayah yang terkena dampak atau memiliki titik api.

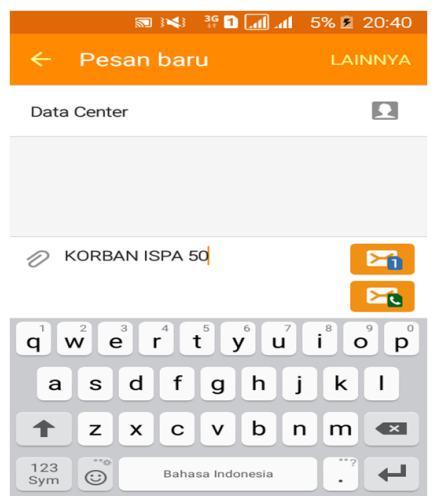

Gambar 6a Pelaporan titip api dengan SMS Gateway

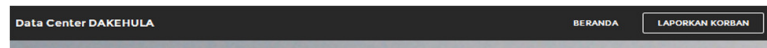

LAPOR KORBAN

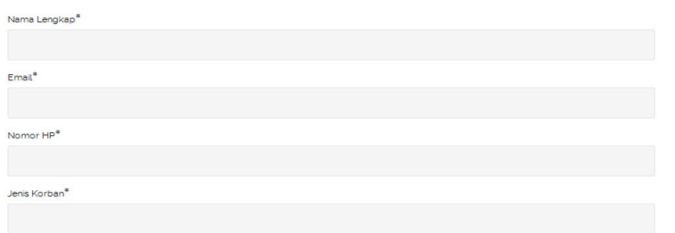

Gambar 6b Tampilan Form Pelaporan berbasis Desktop dan Mobile Web

Untuk dapat mengakses aplikasi bagian sisi Admin juga telebih dahulu harus login dengan hak akses admin. Pada menu utama bagian admin dapat dilhat menu dari form yang dapat dilakukan dari sisi admin seperti: melihat data korban, melihat data lokasi titik api, melihat statistik dari korban bencana dan statistik kejadian munculnya titik api. Pada menu ini juga melihat sistem monitoring semua kejadian yang ada dari waktu-kewaktu. Informasi ini disajikan dalam bentuk GIS. Untuk lebih jelas dapat dilihat pada gambar 7. 


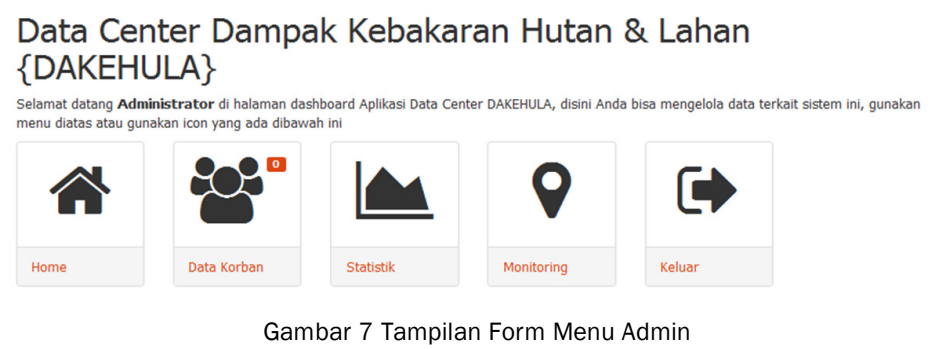

Informasi keseluruhan dari titik api dan daerah yang terdapat korban dapat dilihat pada gambar 8. Informasi ditampilkan dalam bentuk GIS. Masing-masing warna dari legend dipeta mewakili dari kejadian yang terjadi, misalnya warna merah untuk lokasi titik api, biru untuk korban mengungsi, abu-abu untuk mewakili korban ISPA, kuning untuk mewakili korban meninggal dan hijau untuk mewakili titik api yang sudah padam.
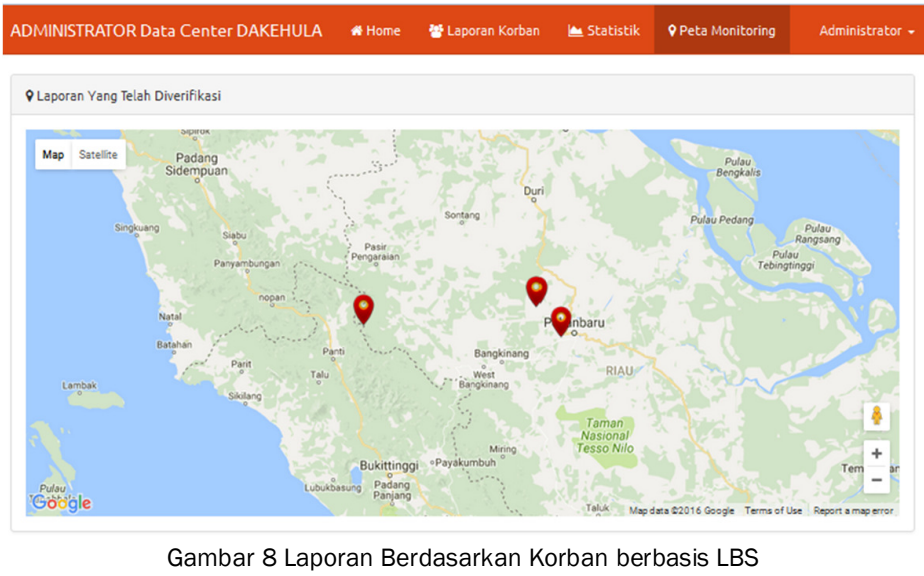

\section{KESIMPULAN}

Pelaporan titik api yang menggunakan SMS masih menggunakan titik koordinat LBS secara manual sehingga posisi koordinat belum tepat. Data korban akan semakin valid jika selalu di upadate oleh operator. Proses update data dilakukan setiap hari. Karena data yang di update menggunakan SMS maka server SMS gateway juga harus selalu di aktifkan 24 jam.

\section{UCAPAN TERIMA KASIH}

Penulis mengucapkan terima kasih kepada Universitas Riau yang telah membiayai penelitian ini melalui dana Hibah PNBP Penelitian Dosen Muda Tahun 2016.

\section{REFERENSI}

[1] Sutabri. Tata. 2012. Konsep Sistem Informasi. Yogyakarta: Andi Offset.

[2] Safaat., Nazaruddin. 2015. Rancang Bangun Aplikasi Multiplatform. Bandung: Informatika.

[3] Azyat, Abdelilah., Raissouni , Naoufal., Achhab, N. B., Lahraoua, Mohamad and Chahboun, Asaad. 2012.Mobile Geographic Information System Platform (MGISP): A GPS Information Collection System. International Journal of Information\&NetworkSecurity(IJINS). Vol.1, No.2, June 2012, pp. 140 151.

[4] Anwar, Badrul., Jaya, Hendra., Kusuma, P.I. 2014. Implementasi Location Based Services Berbasis Android Untuk Mengetahu Posisi User. Jurnal IImiah SAINTIKOM.

[5] Nasaruddin, YudhaNurdin, Roslidar. 2014. The Development of Online Disaster Information System UsingLocation Based Service (LBS) Technology. International Journal of Informatics and Communication Technology (IJ-ICT)Vol.3, No.1, February 2014, pp. 47 58.

[6] Shalahuddin,M. Dan Rosa A. S. 2015. Rekayasa Perangkat Lunak Terstruktur dan Berorientasi Objek. Bandung: Informatika. 